\title{
REFERENCES
}

Alexander, C. L., Meyer, R. M. \& Bartley, E. E. (1969). F. Anim. Sci. 29, 746.

Bailey, R. W. (1967). N.Z. Fl agric. Res. Io, 15.

Balch, C. C. (1950). Br. F. Nutr. 4, 36r.

Balch, C. C. (1958). Br. F. Nutr. 12, 330.

Bensadoun, A., Paladines, O. L. \& Reid, J. T. (1962). F. Dairy Sci. Io, I 203.

Blaxter, K. L., Graham, N. McC. \& Wainman, F. W. (1956). Br. f. Nutr. ro, 69.

Campling, R. C. \& Freer, M. (1962). Br. f. Nutr. 16, 507.

Clapperton, J. I. \& Czerkawski, J. W. (1969). Br. F. Nutr. 23, 81 3.

Hungate, R. E. (1966). The Rumen and Its Microbes. New York: Academic Press.

Hungate, R. E. (I968). In Handbook of Physiology, Section 6, Vol. 5, p. 2725 [C. F. Code, editor]. Washington, D.C.: American Physiological Society.

Hydén, S. (1961). LantbrHögsk. Annlr 27, 51.

Orskov, E. R., Fraser, C. \& Kay, R. N. B. (1969). Br. F. Nutr. 23, 217.

Poutiainen, E. (1968). Annls Agric. fenn. 7, Suppl. 3 .

Thomson, D. J., Armstrong, D. G. \& Prescott, J. H. D. (1969). Proc. Eur. Grassld Fedn, Third Meeting, Braunschweig, p. 253 .

Thomson, D. J., Beever, D. E., Coehlo da Silva, J. F. \& Armstrong, D. G. (1969). Proc. Nutr, Soc. $28,24 \mathrm{~A}$.

Troelsen, J. E. \& Campbell, J. B. (1968). Anim. Prod. ro, 289.

Warner, A. C. 1. \& Stacy, B. D. (I968a). Br. F. Nutr. 22, 369.

Warner, A. C. I. \& Stacy, B. D. (I $968 b$ ). Br. J. Nutr. 22, 389.

Weston, R. H. \& Hogan, J. P. (1968). Aust. Y. agric. Res. 19, 963.

Whitelaw, F. G., Hyldegaard-Jensen, J., Reid, R. S. \& Kay, M. G. (1970). Br. F. Nutr. 24 , I79.

\section{Response of the liver to protein feeding}

By A. Fleck, W. H. Wunner, A. R. Henderson, Fiona C. Ballantyne and W. J. Tilstone, Royal Infirmary, Glasgow

In a review entitled 'Regulation of protein metabolism', Munro (I964) summarized the work up to 1963 on the response of the liver to dietary protein and emphasized the extent of the changes which take place. The early work of Addis, Poo \& Lew (1936) and the subsequent work of Kosterlitz (1947) was definitive. In the rat, $4 \mathrm{~d}$ of feeding a protein-free diet leads to a reduction in liver protein of about $25 \%$ (Addis et al. 1936), and corresponding changes in phospholipids and nucleic acids (Kosterlitz, 1947). Numerous studies of the effects of protein deprivation and refeeding have been carried out (see Munro, i 964). Lagerstedt (1949), for example, illustrated the disappearance of RNA from both cytoplasm and nucleolus during starvation and its reappearance on feeding a high-protein diet. The cellular control mechanisms involved in these changes is discussed in an extensive review by Munro ( $197^{\circ}$ ). The aim of the present paper is to review and collect together our own work on the response of the liver to protein feeding.

It has been recognized for some years that changes occur in the endoplasmic reticulum, or microsome fraction of homogenized tissue, when the protein content of the diet is altered (Bernhard \& Rouiller, 1956). This earlier work described the changes following starvation; however, Wunner $(1967 b)$ confirmed that similar changes occurred in animals given amino acid deficient mixtures. Protein deprivation 
leads to a rapid fragmentation of the endoplasmic reticulum whereas feeding protein or a complete amino acid mixture leads to an increase in this 'rough surfaced' membrane. This confirms some earlier analytical work summarized in Table I, illustrating that the loss of $\mathrm{RNA}$, protein and phospholipid from the microsome fraction was approximately $25 \%$ after $5 \mathrm{~d}$ of protein deprivation.

\begin{tabular}{cccc} 
Table I. & Changes in rat liver following protein deprivation \\
\multicolumn{4}{c}{ Total } \\
Component & homogenate & Microsomes & Cell sap \\
RNA & 23 & 26 & 16 \\
Protein & 23 & 23 & 28 \\
Phospholipid & 33 & 25 & -
\end{tabular}

Figures refer to the percentage decrease of the protein-deprived group. Values from animals given $29 \%$ casein taken as $100 \%$. Diets were given isocalorically for $5 \mathrm{~d}$. Data from Fleck (r964).

Following the description by Wettstein, Staehelin $\&$ Noll $(1963)$ of the preparation of polysomes from the microsome fraction of rat liver and their activity for protein synthesis, it became obvious that changes in polysomes should follow protein deprivation. However, an experimental difficulty led to a modified approach. Both Fleck and Wunner found it impossible to obtain satisfactory polysome patterns from animals shortly after the feeding of a 'balanced' diet, i.e. a mixture of protein, carbohydrate and fat (unpublished observations). Recently, Lowe \& Hallinan (1970), using prolonged centrifugation, have obtained polysome patterns in these circumstances. However, we have still experienced difficulty in obtaining satisfactory polysome patterns from livers with a high glycogen content. These problems led to the use of tube-fed amino acid mixtures as the dietary stimulus. Animals that were fed a complete balanced amino acid mixture $\left(\mathrm{T}^{+}\right)$showed a normal polysome pattern whereas those that were fed the same mixture lacking tryptophan $\left(\mathrm{T}^{-}\right)$showed a breakdown pattern, manifested by an increased amount of free ribosomes and oligosomes (monosomes to 'pentasomes') (Fleck, Shepherd \& Munro, I965; Wunner, Bell \& Munro, I966). We have found it convenient to express changes as the ratio of dimers to polymers $(\mathrm{d}: \mathrm{p})$ in attempting to compare results from different experiments quantitatively. The complementary study of $\left[{ }^{14} \mathrm{C}\right]$ leucine uptake in vitro by the microsome fraction prepared from $\mathrm{T}^{+}$fed animals showed greater incorporation of $\left.{ }^{14} \mathrm{C}\right]$ leucine than the microsomes from $\mathrm{T}-$ fed animals (Fleck et al. $\mathrm{r}_{965}$ ). Both these effects were clearly evident within $\mathrm{I} h$ after feeding.

In these in vivo dietary studies the omission of tryptophan induced the most marked response. Although the omission of other amino acids such as threonine, and to a lesser extent methionine, also produces a similar response in liver polysomes, the breakdown patterns were not so clearly defined as those following the omission of tryptophan (Wunner, ${ }_{1967} a$ ). We suggest that this is due to differences in availability of the various amino acids in vivo. This is supported by the observation of Baliga, Pronczuk \& Munro (Ig68) that in vitro the omission of each of the essential amino acids in turn (with the exception of isoleucine) from an otherwise complete mixture led to a failure of restoration of polysome aggregates which did, however, aggregate normally when a complete amino acid mixture was added. 
Having demonstrated that tryptophan was the most limiting amino acid in its availability, the next stage was to attempt to demonstrate that incorporation of the amino acid into protein correlated with the polysome response. For example, formyl-1-kynurenine, which is not incorporated into protein, when ingested after polysome breakdown had been induced by feeding a $\mathrm{T}^{-}$mixture, fails to restore the normal polysome profile; whereas refeeding with tryptophan, or N-formyl tryptophan, which is incorporated into protein, does restore the normal pattern (Wunner, Forgie \& Henderson, 1968).

It should be emphasized that changes in polysome patterns can be induced by various stimuli. Examples include handling and associated stresses to the animal, injections, anoxia and anaesthetics. We have investigated the effects of various anaesthetics (Tilstone, Wunner and Fleck, unpublished observations) as an essential preliminary to a study of the interaction of injury and the liver response to feeding. It was found that anaesthesia with halothane-oxygen produced virtually no distortion of the normal polysome profile and did not interfere with the $\mathrm{T}^{+}$and $\mathrm{T}^{-}$feeding response whereas other agents were unsatisfactory. The importance of maintaining carefully controlled conditions in these short-term dietary experiments can be illustrated by the following example. As we have outlined above, the observed difference in the polysome profiles $2 \mathrm{~h}$ after feeding with the $\mathrm{T}^{+}$and $\mathrm{T}^{-}$mixtures, can be expressed as an increased dimer:polymer ratio in the $\mathrm{T}^{-}$fed animals relative to that in the $\mathrm{T}^{+}$animals. However, this response is modified after injury (closed fracture of the femur) of experimental rats. Instead of the usual response to feeding the complete mixture, injured animals fed the $\mathrm{T}^{+}$diet showed a 'breakdown' pattern (increased dimer content) which became most marked $\mathrm{I} 8 \mathrm{~h}$ after injury (Fig. I).

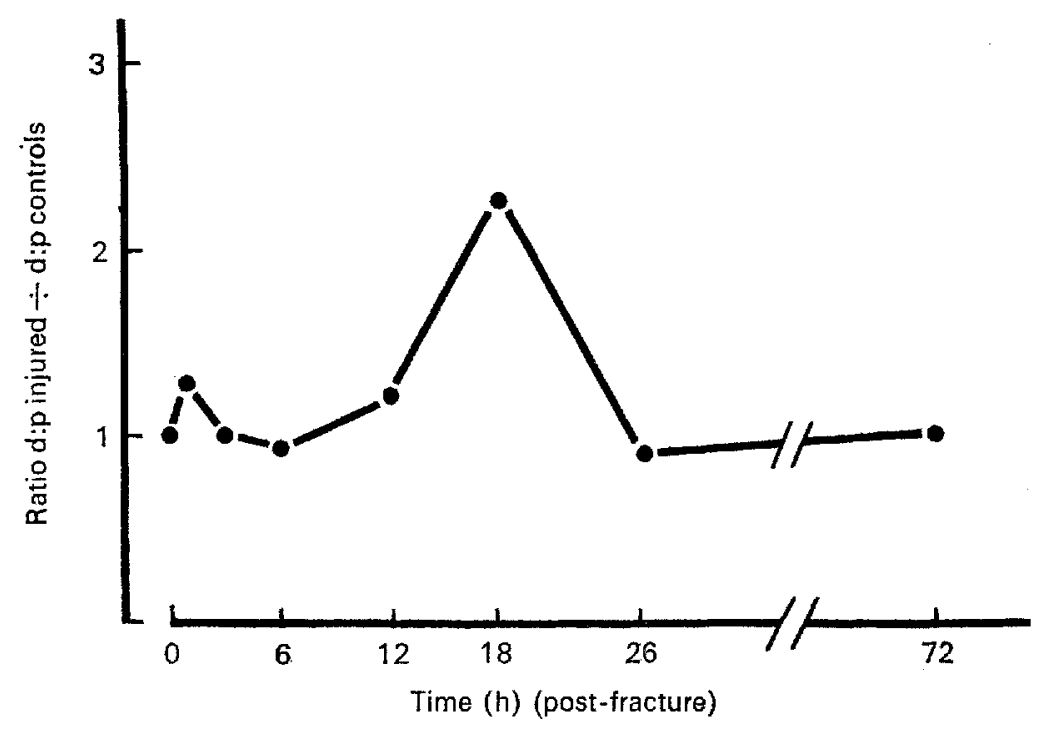

Fig. I. Polysomes and injury. Experimental rats were subjected to closed fracture of the fernur under halothane-oxygen anaesthesia. At the indicated times after injury, the livers were removed, polysomes prepared and the dimer: polymer ratio $(d: p)$ determined from the photometer chart record. All animals were given a complete amino acid mixture $\left(\mathrm{T}^{+}\right) \mathrm{h}$ h prior to being killed. 
The mechanism leading to the differences in polysome patterns has been the subject of speculation and investigation. Initially it was thought that since polysomes consist of ribosomes linked by a single strand of messenger RNA the changes in polysome patterns reflected changes in messenger RNA synthesis. Early doubts of this hypothesis, however, arose when it was found that although the administration of actinomycin $\mathrm{D}$ led to the expected gross breakdown patterns it did not eliminate differences between feeding the $\mathrm{T}^{+}$and $\mathrm{T}^{-}$amino acid mixtures. This occurred in in the presence of a dose of actinomycin D which should have blocked RNA synthesis and thereby suggests the existence of a cytoplasmic control mechanism (Fleck et al. 1965).

However, several workers had observed that changes also occur in the nucleus after alteration of dietary protein intake. Lagerstedt (1949) and Stenram (1958) had described changes in the nucleolus following starvation and refeeding with protein. The nucleolus decreases in size during starvation and increases rapidly after protein feeding. Henderson ( 1970 ) demonstrated that the $\mathrm{Mg}^{2+}$-activated DNA-dependent RNA-polymerase activity of rat liver nuclei changes very rapidly in response to amino acid ingestion. This enzyme was studied because it is known to be a nucleolar enzyme (Siebert, Villalobos, Ro, Steele, Lindenmayer, Adams \& Busch, 1966 ) and because it is thought to synthesize ribosomal RNA (Widnell \& Tata, I966). Animals fed with the complete mixture show higher levels of this enzyme activity than the $\mathrm{T}$ - fed group; peak activity of the enzyme occurred $\mathrm{I} h$ after feeding. In addition, the polymerase activity in the nuclei of normally ad lib. fed animals was approximately $30 \%$ higher than animals fasted for $18 \mathrm{~h}$. The increased polymerase activity was found from 5-10 min after feeding the complete amino acid mixture.

In order to demonstrate that the polymerase response was due direct to the dietary amino acids, Henderson (1970) determined the level of free tryptophan in rat plasma and liver. There were clear differences in free plasma tryptophan and liver free tryptophan in the $\mathrm{T}^{+}$and $\mathrm{T}^{-}$fed animals. Peak levels in liver and plasma occurred I $\mathrm{h}$ after feeding and there was good correlation between polymerase activity and liver free tryptophan.

These changes in both the nucleus and cytoplasm discussed above are early responses, occurring $\mathrm{I}-2 \mathrm{~h}$ after the ingestion of amino acids. Before discussing possible interrelations or control mechanisms, the results of another series of experiments are relevant.

It is commonly assumed that changes occur uniformly (in the statistical sense) in all the cells of the liver. Some doubt was first raised by the demonstration by Hamashima, Harter \& Coons (1964) that not all liver cells fluoresced when histological sections were treated with fluorescent antibodies to either albumin or fibrinogen. This observation was confirmed and extended by Chandrasakharam, Fleck \& Munro $(1967)$ who found that there were more fluorescent cells in sections from animals fed a high-protein (HP) diet containing $29 \%$ casein than in those from animals fed a low-protein (LP) diet. In collaboration with Dr R. Patrick of Glasgow Royal Infirmary we have recently found that $2 \mathrm{~h}$ after feeding HP diet to 
animals previously maintained on LP diet there is a considerable increase in the number of hepatocytes containing albumin.

These findings suggest that albumin synthesis is increased following protein feeding but not in all the cells of the liver simultaneously. However, it must be remembered that this technique only demonstrates the presence or accumulation of albumin in cells and no direct claims about synthesis or breakdown can be made. Though some albumin may be catabolized by the liver (Hoffenberg, Gordon, Black \& Louis, 1970), kinetic studies of albumin turnover suggest more widespread catabolism (McFarlane, 1964) and the degree of the response to the diet is much greater than the increase in catabolism observed after feeding a high level of dietary protein (Chandrasakharam et al. 1967 ).

In summary, feeding with a complete mixture of amino acids compared with a mixture without tryptophan leads to: (I) increased plasma free tryptophan; (2) increased liver free tryptophan; (3) increased DNA-dependent RNA-polymerase activity; (4) a 'normal' polysome pattern in contrast with the 'breakdown' pattern of the $\mathrm{T}^{-}$group; and $(5)$ increased protein synthesis.

These changes are rapid, all being well established within $\mathrm{I} h$ of feeding. Longerterm changes after protein feeding which may be related direct to these are increased nucleolar RNA and an increase in the quantity and organization of endoplasmic reticulum. The role of messenger RNA in the response to feeding protein, or a complete balanced amino acid mixture, and the related increased ribosomal RNA and endoplasmic reticulum, remain to be investigated in greater detail.

Part of this study wassupported by a grant from the Medical Research Council to A.F.

\section{REFERENCES}

Addis, T., Poo, L. J. \& Lew, W. (1936). \%. biol. Chem. I13, 497.

Baliga, B. S., Pronczuk, A. W. \& Munro, H. N. (1968). F. molec. Biol. 34, 99.

Bernhard, W. \& Rouiller, C. (1956). F. biophys. biochem. Cytol. 2, Suppl., p. 73.

Chandrasakharam, N., Fleck, A. \& Munro, H. N. (1967). F. Nutr. 92, 497.

Fleck, A. (1964). Studies in plasma protein metabolism. PhD Thesis, University of Glasgow.

Fleck, A., Shepherd, J. \& Munro, H. N. (1965). Science, N.Y. 150, 628.

Hamashima, Y., Harter, J. G., \& Coons, A. H. (r964). F. cell. comp. Physiol. 20, 27 r.

Henderson, A. R. (1970). Biochem. F. 120, 205 .

Hoffenberg, R., Gordon, A. H., Black, E. G. \& Louis, L. N. (1970). Biochem. F. 118, 401.

Kosterlitz, H. W. (1947). F. Physiol., Lond. 106, 194.

Lagerstedt, S. (1949). Acta Anat. Suppl. no. 9, p. I.

Lowe, D. \& Hallinan, T. (1970). Biochem. F. 117, 64P.

McFarlane, A. S. (1964). In Mammalian Protein Metabolism Vol. x, p. 297 [H. N. Munro, and J. B. Allison, editors]. New York \& London: Academic Press.

Munro, H. N. (1964). In Mammalian Protein Metabolism Vol. 1, p. $3^{82}$ [H. N. Munro and J. B. Allison, editors]. New York \& London: Academic Press.

Munro, H. N. (1970). In Mammalian Protein Metabolism Vol. 4, p. 299 [H. N. Munro and J. B. Allison, editors]. New York \& London: Academic Press.

Siebert, G., Villalobos, J., Ro, T. S., Steele, W. J., Lindenmayer, G., Adams, H. \& Busch, H. (I966). F. biol. Chem. 24r, 7r.

Stenram, U. (1958). Expl Cell Res. 15, 174.

Wettstein, F. O., Staehelin, T. \& Noll, H. (1963). Nature, Lond. 197, 430.

Widnell, C. C. \& Tata, J. R. (1966). Biochim. biophys. Acta 123, 478.

Wunner, W. H. (1967a). Proc. Nutr. Soc. 26, 153.

Wunner, W. H. (1967b). Biochem. F. 103, 71P.

Wunner, W. H., Bell, J. \& Munso, H. N. (1966). Biochem. F. ror, 417.

Wunner, W. H., Forgie, S. \& Henderson, A. R. (1968). Proceedings of the Fifth Meeting of Fedn Eur. biochem. Soc., Prague. London: Academic Press (Inc.) Ltd. 